\title{
Assessment of trout populations inhabiting the Palena River, southern Chile
}

\author{
Sandra Bravo ${ }^{1}$, Ken Whelan ${ }^{2} \&$ María Teresa Silva ${ }^{3}$ \\ ${ }^{1}$ Universidad Austral de Chile, Puerto Montt, Chile \\ ${ }^{2}$ University College Dublin, Dublin, Ireland \\ ${ }^{3}$ Universidad San Sebastián, Puerto Montt, Chile \\ Corresponding author: Sandra Bravo (sbravo@uach.cl)
}

\begin{abstract}
A survey of trout species was carried out to assess the trout stocks' quality inhabiting the Palena River Basin, one of the most important rivers for recreational angling in Chilean Patagonia. Six sampling campaigns were carried out over 16 selected stretches of the river between February 2012 and June 2013. A total of 912 trout were collected, 57\% rainbow trout (Oncorhynchus mykiss), 33.3\% brown trout (Salmo trutta), and $9.6 \%$ brook trout (Salvelinus fontinalis). Also, one tiger trout (Salmo trutta $\times$ Salvelinus fontinalis) (a hybrid between brown and brook trout) was recorded. Results showed that both rainbow trout and brown trout shared the same reaches of the river, with very similar feeding habits, while brook trout inhabited smaller and more enclosed streams. Maturity stages (V-VI) were recorded from the fish sampled over the period spring-summerautumn in the case of rainbow trout; autumn-winter for brook trout, and summer-autumn for brook trout. One of the study's most notable features was the small size of the mature brook trout, reaching $17.5 \mathrm{~cm}$ in length for gravid females and $12.4 \mathrm{~cm}$ for mature males at age $2^{+}$. The maximum age recorded for rainbow and brown trout was $6^{+}$, with a maximum length of 69.8 and $58.5 \mathrm{~cm}$, respectively, while for brook trout, the maximum age recorded was $3^{+}$for a female with a length of $29.9 \mathrm{~cm}$ length and $2^{+}$for a male of $16.6 \mathrm{~cm}$.
\end{abstract}

Keywords: Oncorhynchus mykiss; Salmo trutta; Salvelinus fontinalis; trout population structure; feeding habits; Chilean Patagonia

\section{INTRODUCTION}

Salmon and trout are not native species to the southern hemisphere. They were introduced to Chile around the 1890s to establish recreational fisheries (Basulto 2003). Rainbow trout (Oncorhynchus mykiss) and brown trout (Salmo trutta) are now widely distributed, in both still and running waters, across vast southern Chile areas. They have adapted well to the southern hemisphere's environmental conditions, and their success seems to be influenced by a context-specific combination of their phenotypic plasticity, low ecosystem resistance, and propagule pressure (Arismendi et al. 2014).

The last major restocking program in southern Chile was Government funded and carried out in 1981-1982. Many trout eggs and fry, of both rainbow trout and brown trout, were planted in waters across Chilean Patagonia (Dazarola 2019). The escape of farmed rainbows has also supplemented wild stocks of rainbow trout. However, it is not at all clear that the progeny of these farmed escapes or the progeny of crosses between farmed and wild trout have added significantly to the already well-established wild strains of spawning rainbow trout. (Soto et al. 2006, Arismendi et al. 2011a, 2012, 2014, Sepúlveda et al. 2013).

Not a great deal is known about the brook trout's (Salvelinus fontinalis) distribution and ecology in southern Chile's rivers. Brook trout are, in fact, a char (Adams et al. 2008) but are more commonly called trout. Brook trout were first introduced from USA to Argentina in 1904, and from Argentina to Chile $\left(33^{\circ} \mathrm{S}\right)$ in 1907. Additional stocking of brook trout for fisheries enhancement purposes, which originated from farmed populations, took place between 1920-1940 in the rivers located in the country's central regions $\left(33^{\circ} \mathrm{S}\right)$. However, to this day, there are no records of this district's species (Dazarola 2019). Wild stocks of brook trout have only been recorded in Chilean Patagonia (43$47^{\circ} \mathrm{S}$ ), and their presence in this region may be due to their spread from Argentina through cross border rivers

Corresponding editor: Eduardo Ballester 
such as the Palena River. Several significant introductions of fertilized ova of brook trout were carried out from USA to Patagonia, Argentina, over 1904-1909. Brook trout were continuously stocked into Argentinian rivers until 1924 when rainbow trout were first introduced (Macchi et al. 2008). Brook trout appear to be sensitive to the introduction of brown and rainbow trout into areas they have colonized and are often displaced by these larger and faster-growing trout species (Raleigh 1982).

Rainbow trout and brown trout are much sought after by sport fishermen and are the most widely introduced game fish species worldwide. If the environmental conditions are suitable, brown trout, in particular, will readily invade, thrive, and establish selfsustaining populations. The species is considered one of the world's 100 most invasive alien species and is blamed for reducing native fish populations, especially salmonids, due to predation, displacement, and food competition (Jonsson \& Jonsson 2011). Through their introduction by man, brown trout have now colonized all of the continents on earth, including Antarctica, where both resident and large migratory forms (sea trout) are to be found as far south as the Kerguelen Islands $\left(49^{\circ} 15^{\prime} \mathrm{S}, 69^{\circ} 35^{\prime} \mathrm{W}\right)$, a French protectorate in the southern Indian Ocean (Davaine \& Bealle 1992).

Recreational fisheries are today considered one of the major economic activities taking place in remote areas. As a result of the quality of the wild trout fishing, the beauty of the landscapes, the range and diversity of pristine angling waters, the recreational angling industry is projected to grow strongly in Chilean Patagonia overs the years to come. In this way, this study aimed to assess the trout species' population structure inhabiting the Palena River to establish a sustainable recreational fishery.

\section{MATERIALS AND METHODS}

\section{Study area}

The study was carried out on the Palena River Basin $\left(43^{\circ} 14^{\prime} \mathrm{S}, 71^{\circ} 07^{\prime} \mathrm{W} ; 44^{\circ} 35^{\prime} \mathrm{S}, 72^{\circ} 58^{\prime} \mathrm{W}\right)$. The Palena River originates in Argentina and flows from PalenaVinter Lake, a border lake shared by Chile and Argentina, to the Pacific Ocean. Its total watershed area comprises $12,867 \mathrm{~km}^{2}$, of which $5,606 \mathrm{~km}^{2}(43.5 \%)$ lies in Argentina and 7,281 km² (56.5\%) in Chile.

\section{Sampling sites}

Between February 2012 and June 2013, six surveys, covering the four seasons of the year, were undertaken (Table 1). Throughout the study, 16 areas were sampled along the river and its tributaries (Fig. 1).

\section{Sampling methods}

Fish were sampled using electrofishing for the smaller fish and angling for the larger fish. The largest fish was caught by local anglers who collaborated in the study. All fish collected by electrofishing were kept alive in a large container of fresh, cold water. They were anesthetized with benzocaine ( $10 \%$ in ethanol, $1 \mathrm{~mL} \mathrm{~L}^{-1}$ ) before measuring $(\mathrm{mm})$ and weighing $(\mathrm{g})$. A proportion of the fish, representative of the different development stages, were retained for subsequent laboratory analysis, and the others were safely returned to the water. Fish were classified as fry $(<10 \mathrm{~cm})$, juveniles $(10-24 \mathrm{~cm})$, and adults $(>24 \mathrm{~cm})$. Fulton condition factor $(\mathrm{K})$ was calculated as $\mathrm{K}=100 \times \mathrm{W} \times \mathrm{L}^{-3}$, where $\mathrm{W}$ : weight in grams and $\mathrm{L}$ : fork length in $\mathrm{cm}$.

\section{Age analysis}

Scales collected from fish were prepared following the Celtic Sea Trout Project Workshop recommended methodology (Poole 2010) to determine each fish's age from each of the length classes. Scales were removed from an area below the posterior margin of the dorsal fin and approximately five scale rows above the lateral line (Pascual et al. 2001, Riva-Rossi et al. 2007). Five cleaned scales from each fish were mounted and read using a microfiche projector.

\section{Sexual maturation}

Maturity stages were defined following the key recommended by Dahl (1917) for trout. Since salmonids are total spawners, the manual of fisheries science (FAO 1975) was also used when assessing the maturity of the adult fish.

\section{Feeding habits}

The stomachs of the fish were removed and the contents preserved in $95 \%$ ethanol for later examination. Stomach contents were analyzed with a dissecting microscope, using taxonomic keys to the lowest possible taxa, which in this study was classified to the order stage of classification. Prey was weighed and counted.

The relative abundance is calculated as the number of each prey item over the total number of items registered in the sample. Frequency of occurrence $(\mathrm{FO} \%)$ was calculated as the number of stomachs containing a prey item, divided by the total number of non-empty stomachs, expressed as a percentage (Macdonald \& Green 1983). The Shannon's diversity index $(\mathrm{H})$ was calculated as the proportion of the prey items $i$ relative to the total number of the prey items $\left(p_{i}\right)$, and then multiplied by the natural logarithm of this proportion $\left(\ln \left(p_{i}\right)\right)$. The resulting product was summed across the prey items and multiplied by -1 . 
Table 1. The number of fish caught per sampling zone.

\begin{tabular}{|c|c|c|c|c|c|c|c|}
\hline \multirow{3}{*}{ Zone } & \multicolumn{7}{|c|}{ Species } \\
\hline & \multicolumn{2}{|c|}{ Rainbow trout } & \multicolumn{2}{|c|}{ Brown trout } & \multicolumn{2}{|c|}{ Brook trout } & \multirow[t]{2}{*}{$\mathrm{n}$} \\
\hline & $\mathrm{n}$ & $\%$ & $\mathrm{n}$ & $\%$ & $\mathrm{n}$ & $\%$ & \\
\hline 1 & 0 & 0.0 & 0 & 0.0 & 2 & 100.0 & 2 \\
\hline 2 & 43 & 66.1 & 17 & 26.2 & 5 & 7.7 & 65 \\
\hline 3 & 43 & 59.7 & 29 & 40.3 & 0 & 0.0 & 72 \\
\hline 4 & 11 & 84.6 & 2 & 15.4 & 0 & 0,0 & 13 \\
\hline 5 & 16 & 80.0 & 4 & 20.0 & 0 & 0.0 & 20 \\
\hline 6 & 103 & 78.6 & 28 & 21.4 & 0 & 0.0 & 131 \\
\hline 7 & 15 & 46.9 & 16 & 50.0 & 1 & 3.1 & 32 \\
\hline 8 & 149 & 54.6 & 78 & 28.6 & 46 & 16.8 & 273 \\
\hline 9 & 0 & 0.0 & 3 & 60.0 & 2 & 40.0 & 5 \\
\hline 10 & 17 & 50.0 & 9 & 26.5 & 8 & 23.5 & 34 \\
\hline 11 & 5 & 33.3 & 10 & 66.7 & 0 & 0.0 & 15 \\
\hline 12 & 31 & 68.9 & 14 & 31.1 & 0 & 0.0 & 45 \\
\hline 13 & 10 & 25.0 & 29 & 72.5 & 1 & 2.5 & 40 \\
\hline 14 & 3 & 30.0 & 7 & 70.0 & 0 & 0.0 & 10 \\
\hline 15 & 74 & 54.0 & 58 & 42.3 & 5 & 3.7 & 137 \\
\hline 16 & 0 & 0.0 & 0 & 0.0 & 18 & 100.0 & 18 \\
\hline Total & 520 & 57.0 & 304 & 33.3 & 88 & 9.6 & 912 \\
\hline
\end{tabular}
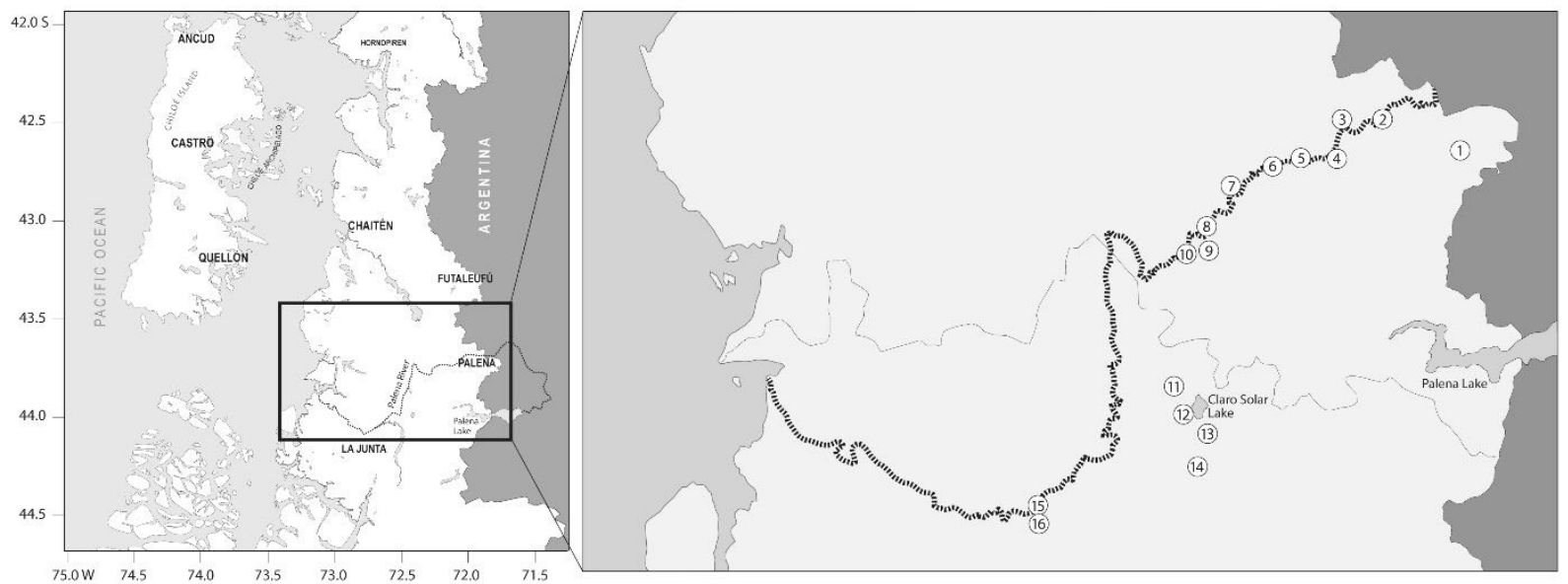

Figure 1. Map showing the sampled sectors in the Palena River basin and its tributaries.

\section{Data analysis}

IBM $^{\circledR}$ SPSS ${ }^{\circledR}$ Statistic 20.0 SPSS, and Microsoft Office Professional Plus 2013 software were used for statistical analysis of the data. Descriptive statistics were used for tables and graphs. The Kruskal-Wallis test and the Mann-Whitney test were used to compare the condition factor between species for the same development stage, while the Mann-Whitney test was used to assess differences in size between males and females for the same age. Results were considered statistically significant at $P \leq 0.05$. The ratio of weight and length between fish, according to species, was calculated through a regression model.

\section{RESULTS}

\section{Abundance and seasonal distribution}

Over the period of study 913 trout were collected: 520 rainbow trout Oncorhynchus mykiss (57\%); 304 brown trout Salmo trutta (33.3\%); 88 brook trout Salvelinus fontinalis (9.6\%) and one tiger trout Salmo trutta $\times$ Salvelinus fontinalis $(0.1 \%)$. The tiger trout, a hybrid between brown and brook trout, was recorded in summer 2013 in a small tributary stream inhabited by brook trout and brown trout. The tiger trout was released alive following weighing and measuring. The 
Table 2. Trout abundance per species, stage of development, and season.

\begin{tabular}{|c|c|c|c|c|c|c|c|c|c|c|c|c|}
\hline \multirow{2}{*}{ Year season } & \multicolumn{3}{|c|}{ Rainbow trout } & \multirow[b]{2}{*}{ Total } & \multicolumn{4}{|c|}{ Brown trout } & \multicolumn{3}{|c|}{ Brook trout } & \multirow[b]{2}{*}{ Total } \\
\hline & Fry & Fingerling & Adult & & Fry & Fingerling & Adult & Total & Fry & Fingerling & Adult & \\
\hline \multicolumn{13}{|l|}{2012} \\
\hline Summer & 119 & 2 & 2 & 123 & 46 & 2 & 0 & 48 & 0 & 5 & 0 & 5 \\
\hline Autumn & 44 & 7 & 15 & 66 & 39 & 6 & 9 & 54 & 3 & 16 & 0 & 19 \\
\hline Winter & 80 & 3 & 7 & 90 & 40 & 14 & 14 & 68 & 12 & 9 & 0 & 21 \\
\hline Spring & 17 & 3 & 33 & 53 & 10 & 5 & 14 & 29 & 14 & 2 & 1 & 17 \\
\hline \multicolumn{13}{|l|}{2013} \\
\hline Summer & 40 & 4 & 21 & 65 & 49 & 3 & 9 & 61 & 6 & 8 & 0 & 14 \\
\hline Autumn & 79 & 29 & 15 & 123 & 24 & 12 & 8 & 44 & 2 & 10 & 0 & 12 \\
\hline Total & 379 & 48 & 93 & 520 & 208 & 42 & 54 & 304 & 37 & 50 & 1 & 88 \\
\hline
\end{tabular}

fish was excluded from further analysis as it represented an isolated finding.

Fry $(<10 \mathrm{~cm})$ was the most abundant life stage recorded for rainbow trout $(72.9 \%)$ and brown trout (68.4\%), while for brook trout, the highest abundance recorded was for fish within the size range $10-25 \mathrm{~cm}$ (56.8\%). The highest abundance of rainbow and brown trout fry was recorded in the summer months, 39.6 and $45.7 \%$, respectively, while brook trout abundance was highest in winter and spring (Table 2).

\section{Size structure and condition factor}

The longest recorded lengths and weight were $68.8 \mathrm{~cm}$ with $3920 \mathrm{~g}$ for rainbow trout, $59.5 \mathrm{~cm}$ with $2775 \mathrm{~g}$ for brown trout, and $29 \mathrm{~cm}$ with $0.255 \mathrm{~g}$ for brook trout (Table 3). The growth relationship between each trout species' length and weight are shown (Figs. 2a-c).

In the case of rainbow trout, the highest condition factor recorded was for the fry stage (1.08), showing significant differences with the fingerlings and adult stages $(P<0.001)$. The highest condition factor for brown trout was also recorded for the fry stage (1.08), but significant differences were only recorded for the fingerling stage $(P=0.003)$. For brook trout, the highest condition factor was recorded for fish $>24 \mathrm{~cm}$; however, no significant differences were recorded between the different stages of development $(P=$ 0.570 ) with average values ranging between 0.95 (fry) and 1.05 (adult). Brown trout showed the highest condition factor for all developmental stages (Fig. 3).

\section{Age structure}

Throughout the study, 308 scales were aged, representing $36.8 \%$ of the total fish sampled from the river. In rainbow trout, 156 scales (30\% of the total caught) were used for aging. The male rainbow trout ranged between ages $0^{+}$and $5^{+}$, with a maximum length of 44.9 $\mathrm{cm}$. Females ranged in age between $0^{+}$to $6^{+}$, with a maximum length of $53.3 \mathrm{~cm}$. No significant differences in length relative to age were recorded between males and females using the Mann-Whitney test (Fig. 4a). A total of 116 brown trout scales (24\% of the total caught) were analyzed. These fish ranged in age between $0^{+}$to $4^{+}$for females (max. length $35.9 \mathrm{~cm}$ ) and between $0^{+}$to $6^{+}$for males (max. length $50 \mathrm{~cm}$ ). Using the MannWhitney test, the only significant difference noted in terms of growth rate between males and females was at age $2^{+}$(Fig. $4 b$ ).

In brook trout, 36 sets of scales $(40.9 \%$ of the total caught) were analyzed. The fish ranged in age between $0^{+}$to $3^{+}$for females (max. length $29.9 \mathrm{~cm}$ ) and $0^{+}$to $2^{+}$, for males, with a maximum length of $16.6 \mathrm{~cm}$. No significant differences were recorded in size relative to age between males and females, using the MannWhitney test (Fig. 4c).

\section{Maturity stages}

Maturity stages were analyzed for 77 females and 113 male rainbow trout (36.5\% of the total caught); 73 female and 91 male brown trout $(53.9 \%$ of the total caught) and 24 female and 60 male brook trout (68.2\% of the total caught). Maturity stages V and VI were recorded for rainbow trout over spring-summerautumn, for brown trout during the autumn-winter period, and brook trout over the summer-autumn period. The most notable feature was the mature brook trout (stage V), at age $2^{+}$and $17.5 \mathrm{~cm}$ in length for females and $12.4 \mathrm{~cm}$ for males (Table 4). Stage VII females, spawned, with diminutive eggs and a small number of large eggs free in the cavity, were recorded in the case of both brown and rainbow trout.

\section{Feeding habits}

Stomachs contents from 396 fish were analyzed, corresponding to $43.4 \%$ of the total fish sampled, com- 
Table 3. Biometric characteristics exhibited by the trout species, according to their stage of development (mean \pm standard deviation, SD).

\begin{tabular}{|c|c|c|c|c|c|c|}
\hline \multirow{2}{*}{ Species } & \multirow{2}{*}{ Status } & \multirow{2}{*}{$\mathrm{n}$} & \multicolumn{2}{|l|}{ Weight $(\mathrm{g})$} & \multicolumn{2}{|l|}{ Length $(\mathrm{cm})$} \\
\hline & & & Mean (range) & SD & Mean (range) & SD \\
\hline \multirow{3}{*}{ Rainbow trout } & Fry & 379 & $3.1(0.2-15)$ & 2.1 & $6.4(2.5-9.9)$ & 1.4 \\
\hline & Fingerling & 48 & $46.3(9.9-127.6)$ & 36.9 & $15.9(10.0-23.6)$ & 4.8 \\
\hline & Adult & 93 & $603.0(65.7-3,920.0)$ & 634.9 & $37.1(24.2-68.8)$ & 9.3 \\
\hline \multirow{3}{*}{ Brown trout } & Fry & 208 & $4.5(0.2-15)$ & 2.7 & $7.1(2.5-9.9)$ & 1.6 \\
\hline & Fingerling & 42 & $28.5(8.6-105.8)$ & 23.7 & $13.8(10.0-21.0)$ & 3.2 \\
\hline & Adult & 54 & $758.3(144.4-2,775.0)$ & 640.4 & $38.3(24.2-59.5)$ & 9.3 \\
\hline \multirow{3}{*}{ Brook trout } & Fry & 37 & $3.9(0.2-8.2)$ & 2.3 & $7.2(2.2-9.7)$ & 1.9 \\
\hline & Fingerling & 50 & $32.0(8.7-148.2)$ & 23.1 & $14.3(10.0-23.6)$ & 2.7 \\
\hline & Adult & 1 & $255.5(-)$ & - & $29(-)$ & - \\
\hline
\end{tabular}
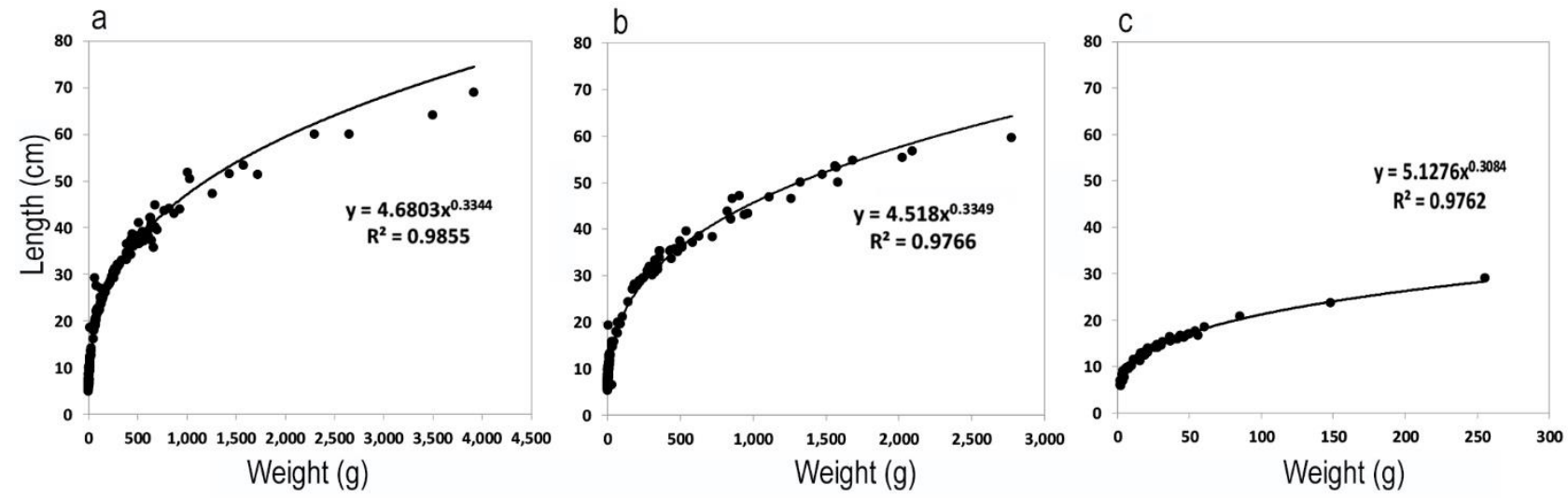

Figure 2. Growth relationship between length and weight of trout species. a) Rainbow trout, b) brown trout, c) brook trout.

prising: 203 from rainbow trout (39\% of the total caught); 154 from brown trout $(50.7 \%$ of the total caught), and 39 from brook trout $(44.3 \%$ of the total caught).

For the three trout species studied, there was an apparent increase in the diversity of food items eaten with the fish's increasing length. Ephemeroptera, Plecoptera, Diptera, and Trichoptera were the main items recorded in the fry stage for the three trout species, while in the fingerling and adult stages, the items Coleoptera and Basomamatophora were included (Table 5)

The only fish recorded as a food item throughout the study was the native species Galaxias maculatus (order Osmeriformes), which was found in a very low frequency of occurrence in adult brown trout (6) and rainbow trout (2). The highest Shannon diversity index was recorded for rainbow trout fingerling and the lowest for adult rainbow trout (Fig. 6).

\section{Rainbow trout}

The main items recorded in the stomachs of rainbow trout fry were the orders Diptera and Ephemeroptera. The most prevalent items in the food of fingerlings were Basomamatophora, Diptera, and Trichoptera. Trichoptera, Diptera, and Basomamatophora were the most common food items in adult trout's stomachs (Fig. 5a). At the fry stage, the frequency of occurrence was highest for Ephemeroptera and Plecoptera, while in the case of fingerlings, the Trichoptera and Ephemeroptera were dominant. The frequency of occurrence was most remarkable for Diptera, Coleoptera, and Basomamatophora in adult rainbows (Fig. 5b).

\section{Brown trout}

The main items recorded from the stomachs of brown trout fry were Ephemeroptera. While the orders Ephemeroptera and Basomamatophora were dominant in the case of fingerling. The main items in adults' stomachs were Basomamatophora, Diptera, and Ephemeroptera 


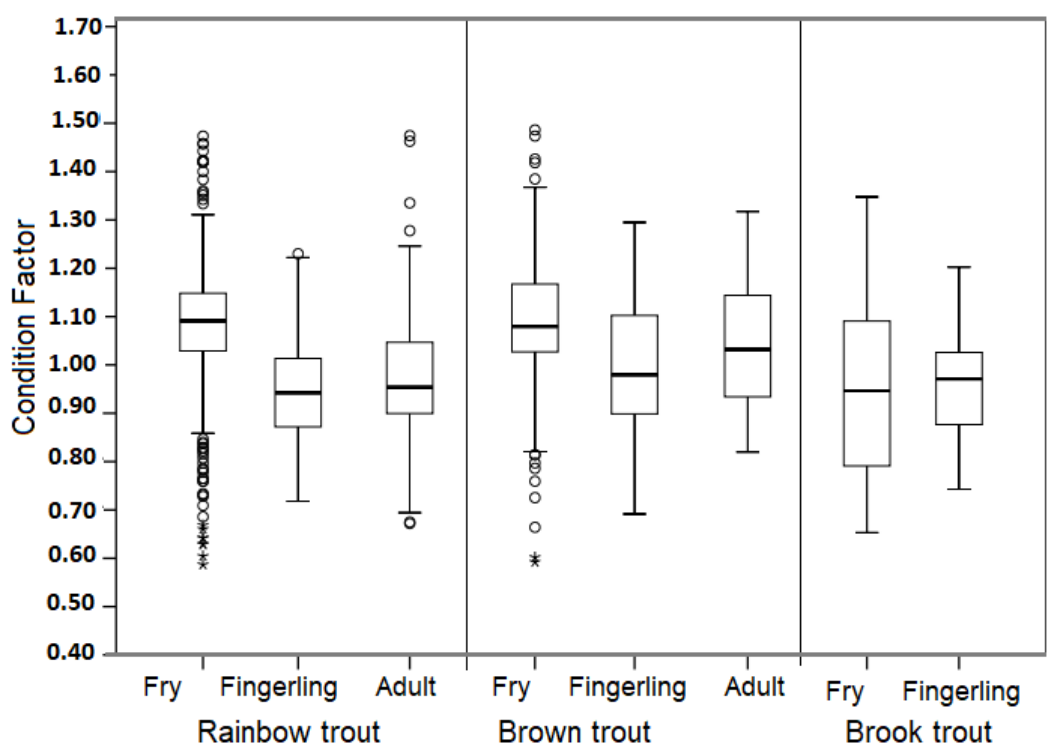

Figure 3. Box plot for condition factor, relative to the length of trout species, by developmental stage.
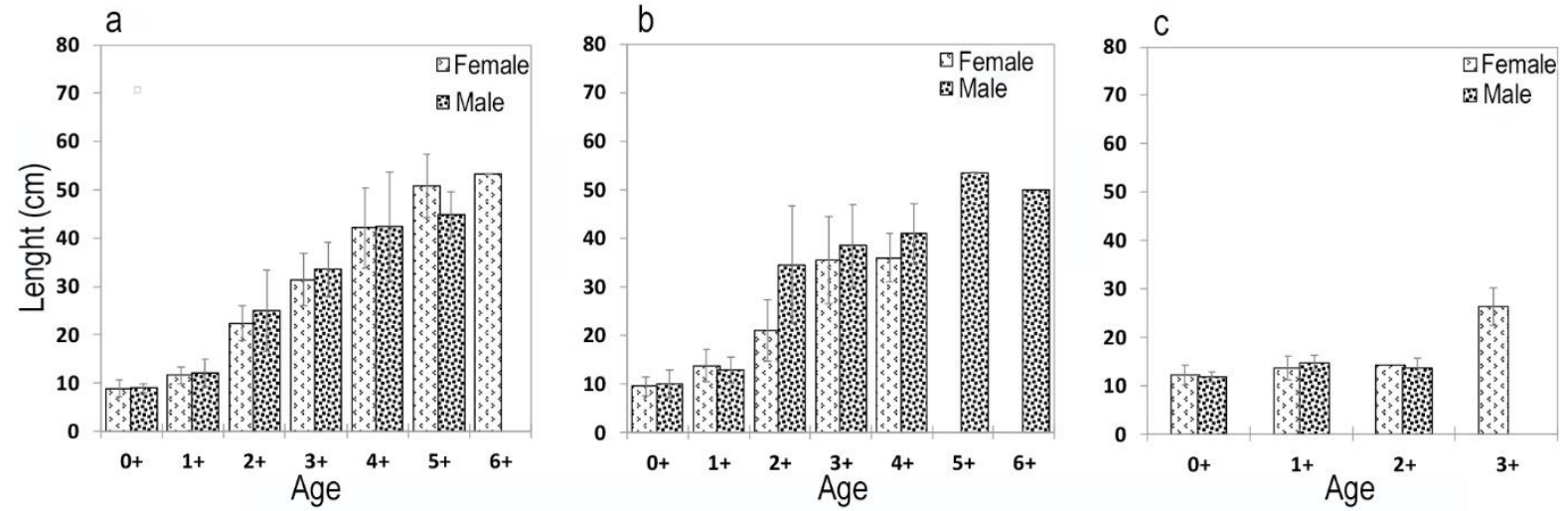

Figure 4. Length and age (mean \pm standard deviation) of male and female trout species. a) Rainbow trout, b) brown trout, c) brook trout.

(Fig. 5c). The frequency of occurrence was highest for Ephemeroptera and Plecoptera's orders in the case of both the fry and fingerling stages, while individuals from the orders Basomamatophora and Trichoptera were most frequently found in the stomachs of adult trout (Fig. 5d).

\section{Brook trout}

The main food items recorded from the stomachs of brook trout fry were Ephemeroptera and Plecoptera. The dominant items in the stomachs of fingerlings were Trichoptera and Basomamatophora (Fig. 5e). The frequency of occurrence was greatest for Plecoptera's order in the fry of brook trout, while the orders Basomamatophora and Decapoda were most frequently encountered in the stomachs of fingerlings (Fig. 5f).

\section{DISCUSSION}

Trout populations in the Palena River consisted primarily of rainbow Oncorhynchus mykiss and brown trout Salmo trutta. Both species shared similar habitats and were found together in 13 of the 16 sampled zones throughout the study, although the abundance of rainbow trout $(57 \%)$ was higher than brown trout (33.2\%) (Table 1). The juvenile rainbow trout were found primarily in the faster-flowing riffles and glides, while the brown trout seemed to favor the pool areas. The Palena River, throughout the study area, was dominated by faster-moving water, which may explain the greater abundance of rainbow trout. In contrast, brook trout Salvelinus fontinalis were only recorded in nine of the sampled areas and at a very low stock densi- 
Table 4. Maturity stages of trout collected, by species, according to their gender. n: number of fish, SD: standard deviation.

\begin{tabular}{|c|c|c|c|c|c|c|c|c|c|c|c|c|}
\hline \multirow{3}{*}{ Maturity } & \multicolumn{4}{|c|}{ Rainbow trout } & \multicolumn{4}{|c|}{ Brown trout } & \multicolumn{4}{|c|}{ Brook trout } \\
\hline & \multicolumn{2}{|r|}{ Female } & \multicolumn{2}{|c|}{ Male } & \multicolumn{2}{|r|}{ Female } & \multicolumn{2}{|c|}{ Male } & \multicolumn{2}{|r|}{ Female } & \multicolumn{2}{|c|}{ Male } \\
\hline & $\mathrm{n}$ & Mean $( \pm$ SD $)$ & $\mathrm{n}$ & Mean $( \pm$ SD $)$ & $\mathrm{n}$ & Mean $( \pm$ SD $)$ & $\mathrm{n}$ & Mean $( \pm$ SD $)$ & $\mathrm{n}$ & Mean $( \pm$ SD $)$ & $\mathrm{n}$ & Mean $( \pm S D)$ \\
\hline I & 35 & $15.6(8.8)$ & 81 & $17.3(12.4)$ & 48 & $12.2(8.1)$ & 70 & $14.1(10.7)$ & 3 & $8.4(2.0)$ & 13 & $10.5(3.6)$ \\
\hline II & 32 & 30.7 (11.6) & 13 & $32.5(11.5)$ & 18 & $23.4(10.7)$ & 6 & $29.9(11.0)$ & 12 & $14.6(5.0)$ & 1 & $15.9(-)$ \\
\hline III & 5 & $43.4(6.8)$ & 5 & $42.7(12.3)$ & 1 & $35(-)$ & 7 & $42(15.1)$ & 4 & $14(6.7)$ & 8 & $13.6(4.2)$ \\
\hline IV & 2 & $48.5(16.3)$ & 9 & $29.5(13.6)$ & 1 & $43.7(-)$ & 2 & $38.9(20.8)$ & 4 & $14.4(3.4)$ & 13 & $12.7(3.3)$ \\
\hline V & - & - & 3 & $50.4(24.7)$ & 2 & $34.7(21.5)$ & 1 & $43.2(-)$ & 1 & $17.5(-)$ & 1 & $12.4(-)$ \\
\hline VI & - & - & 2 & $37.0(7.1)$ & - & - & 5 & $51.3(5.4)$ & & - & & - \\
\hline VII & 3 & $49.3(9.9)$ & & - & 3 & $47.7(8.6)$ & & - & & - & & - \\
\hline
\end{tabular}

Table 5. Prey items found by trout species and by developmental stage.

\begin{tabular}{|c|c|c|c|c|c|c|c|c|}
\hline \multirow[b]{2}{*}{ Items } & \multicolumn{3}{|c|}{ Fry } & \multicolumn{3}{|c|}{ Fingerling } & \multicolumn{2}{|c|}{ Adult } \\
\hline & $\begin{array}{c}\text { Rainbow } \\
\text { trout }\end{array}$ & $\begin{array}{c}\text { Brown } \\
\text { trout }\end{array}$ & $\begin{array}{c}\text { Brook } \\
\text { trout }\end{array}$ & $\begin{array}{c}\text { Rainbow } \\
\text { trout }\end{array}$ & $\begin{array}{c}\text { Brown } \\
\text { trout }\end{array}$ & $\begin{array}{l}\text { Brook } \\
\text { trout }\end{array}$ & $\begin{array}{c}\text { Rainbow } \\
\text { trout }\end{array}$ & $\begin{array}{c}\text { Brown } \\
\text { trout }\end{array}$ \\
\hline Plecoptera & 28.9 & 26.7 & 33.3 & 14.5 & 25.6 & 15.3 & 11.7 & 18.8 \\
\hline Coleoptera & 1.3 & 0.0 & 0.0 & 8.4 & 2.3 & 10.2 & 14.9 & 1.3 \\
\hline Diptera & 25.0 & 12.0 & 33.3 & 18.1 & 14.0 & 8.5 & 18.9 & 18.8 \\
\hline Ephemeroptera & 30.3 & 38.7 & 16.7 & 20.5 & 30.2 & 11.9 & 11.3 & 15.0 \\
\hline Trichoptera & 11.8 & 12.0 & 0.0 & 22.9 & 14.0 & 11.9 & 13.1 & 21.3 \\
\hline Basommatophora & 2.6 & 6.7 & 0.0 & 12.0 & 14.0 & 23.7 & 14.9 & 25.0 \\
\hline Hemiptera & 0.0 & 2.7 & 0.0 & 0.0 & 0.0 & 1.7 & 1.4 & 0.0 \\
\hline Decapoda & 0.0 & 1.3 & 16.7 & 3.6 & 0.0 & 16.9 & 14.0 & 0.0 \\
\hline & 100.0 & 100.0 & 100.0 & 100.0 & 100.0 & 100.0 & 100.0 & 100.0 \\
\hline
\end{tabular}

ty. Just two areas accounted for 52.3 and $20.5 \%$, respectively, of the total number of brook trout collected throughout the study (Table 2).

Since the primary sampling method used was shallow water electrofishing, it is not surprising that the catch mainly consisted of rainbow trout and brown trout fry, 72.9 and $68.4 \%$, respectively (Table 2). In contrast, in brook trout, fingerlings were far more abundant than the fry stage. It may be that the brook trout were reproducing in the smaller tributaries and that the present study was only encountering the older, displaced parr in the areas sampled. The species abundance corresponded to only $9.6 \%$ of the total fish caught throughout the study (Table 1).

Of particular note was a tiger trout (Salmo trutta $\times$ Salvelinus fontinalis) sharing the same habitat as brown trout and the brook trout. The tiger trout is a sterile, hybrid cross between a female brown trout and a male brook trout (Raleigh 1982, Benhke 2002). It is a rare and unique cross in the wild, considering that each trout belongs to a separate genus, appearing only in areas where brook and brown trout share spawning grounds. Naturally occurring tiger trout appear in streams with higher brook trout than brown trout populations (Benhke 1980). In the present survey, brown trout were more abundant than brook trout. Across their native range, brook trout thrive in streams, lakes, and ponds that are cold and clear. They prefer water temperatures between 11 to $16^{\circ} \mathrm{C}$ and are often confined to springfed streams headwaters (Raleigh 1982, Meehan \& Bjornn 1991). In this study, the water temperature in the sampled areas ranged between $6.1^{\circ} \mathrm{C}$ in winter to $16.7^{\circ} \mathrm{C}$ in summer, ideal for salmonids species.

The oldest trout encountered in the case of both rainbow trout and brown trout was $6+$, and the maximum length attained was $68.8 \mathrm{~cm}$ for rainbow trout and $59.5 \mathrm{~cm}$ for brown trout, which is in agreement with previous studies in southern Patagonia (Vigliano et al. 2009, Arismendi et al. 2011a). In contrast, the highest age recorded for the brook trout sampled throughout the study was $3^{+}$for a female and $2^{+}$for a male. The largest brook trout recorded was 26.3 $\mathrm{cm}$ for a female and $14.7 \mathrm{~cm}$ for a male, which agrees with previous information recorded for short-lived brook trout strain. This form ranges between 3-4 years old and attains a length of $200-250 \mathrm{~mm}$. This growth pattern is typically found in cold and lake habitats 

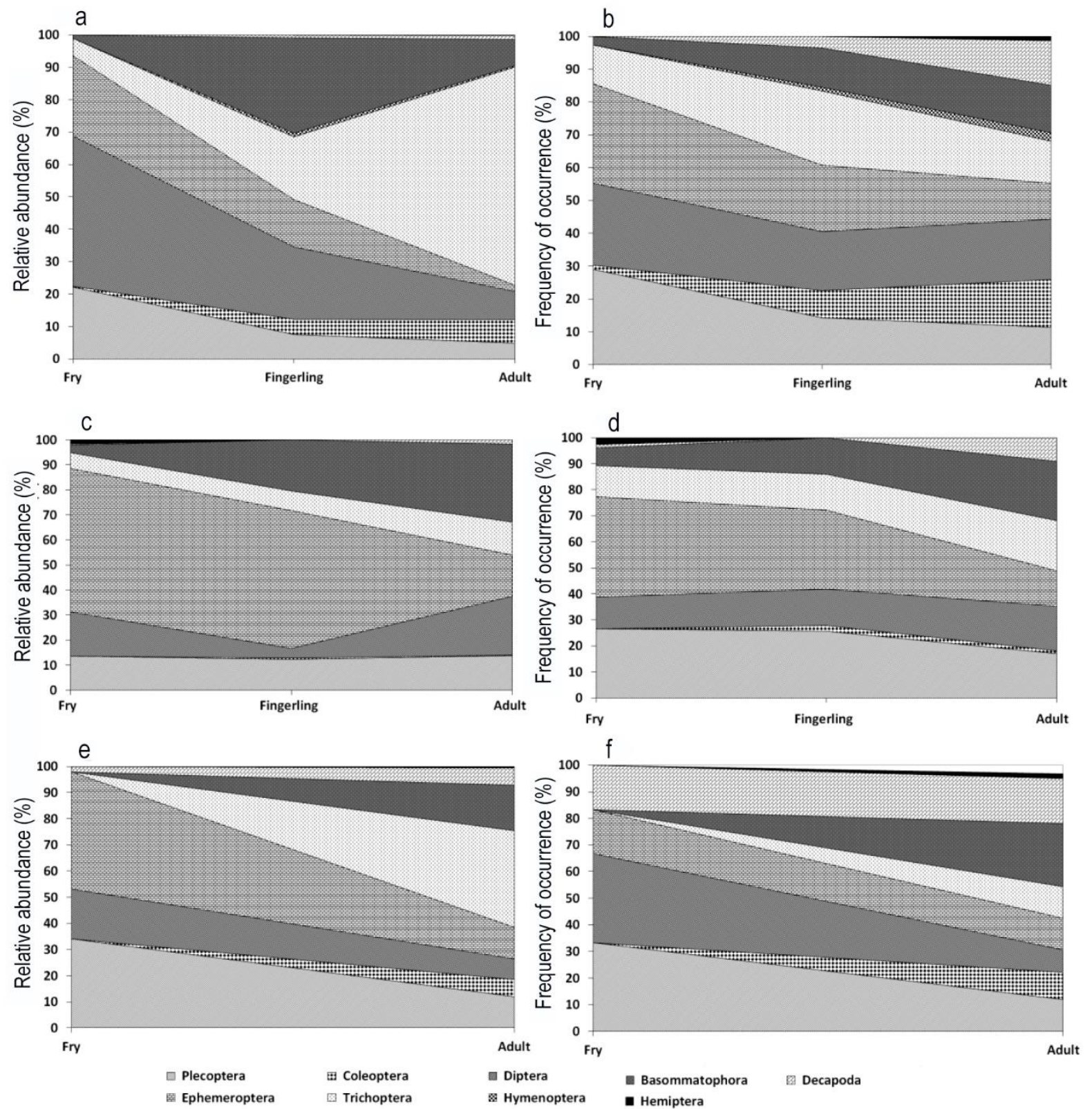

Figure 5. Relative abundance and frequency of occurrence of the food items found in the sampled trout species. a-b) Rainbow trout, c-d) brown trout, e-f) brook trout, respectively, according to the developmental stage.

(Raleigh 1982), similar to the sites where this species was recorded in this study. In Patagonia, Argentina, brook trout are larger on average. They range in length between 35-49 $\mathrm{cm}$ and can reach $5^{+}$years of age (Kuroda et al. 2009, Vigliano et al. 2009), higher than the length and age recorded for brook trout in this study. Although it has been reported that brook trout normally live for some three to five years (Meehan \& Bjornn 1991, Benhke 2002), in large rivers and lakes, brook trout have been recorded to live up to 9 or 10 years of age (Meehan \& Bjornn 1991, Benhke 2002).
This study showed that in the adult stage, the condition factor for rainbow trout averaged 0.97; for brown trout 1.04, and brook trout 1.05. The lowest condition factor (0.95) was recorded for fry and fingerling rainbow trout (Fig. 3), which is in line with results for other salmonid species in southern Patagonia (Kuroda et al. 2009, Arismendi et al. 2011b).

The fish sampled displayed consistently high condition factors, a clear indication that the fish were thriving in an environment rich with food (Froese 2006). 


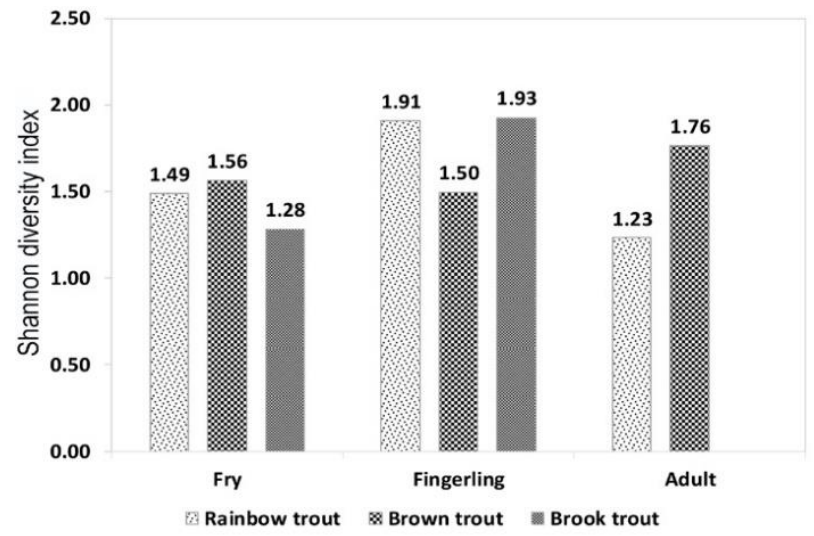

Figure 6. Shannon diversity index of the prey items found by trout species and by developmental stage.

The stomach analysis revealed an abundance of trout food from all developmental stages, from fry to adult fish. Rainbow trout diets show an increase in the diversity of prey items from six at the fry stage to 13 in the adult stage (Fig. 5a). In brown trout, prey diversity increased from 9 to 10 items (Fig. 5c), while in brook trout, the number of prey types increased from four to eight items (Fig. 5e). The most abundant prey items were Trichoptera, Diptera, and Basommatophora for rainbow trout; for brown trout, Ephemeroptera, Basommatophora, and Diptera were prevalent, and for brook trout, the most abundant food items were from the Trichoptera, Ephemeroptera, and Plecoptera. Behnke (2002) reported that brook trout have similar food habitats as brown trout and rainbow trout, and Meehan \& Bjornn (1991) reported that Ephemeroptera, Trichoptera, and Diptera often make up a large component of their diet, which is in agreement with the findings in this study (Table 5).

The highest diversity of food items was recorded in brown trout fry and the adult stage (Fig. 6). Surprisingly both brown and rainbow trout showed a low presence of fish in the stomachs examined, with only a single native fish species, Galaxias maculatus, recorded throughout the study. Because of its generally small size $(<8 \mathrm{~cm})$, G. maculatus is considered as a forage fish and an ideal food source for other larger fish (Ferriz 1984). Other authors have reported that both rainbow and brown trout are primarily responsible for its population decline in southern Chile (Soto et al. 2006, Arismendi et al. 2009, 2012). In contrast, some authors have reported no significant predation occurrence by trout on native Chilean fish (Palma et al. 2002, Buria et al. 2007, 2009).

The period over which the fish matured (stage VVI) in the Palena River was spring-summer-autumn for rainbow trout, autumn-winter for brown trout, and summer-autumn for brook trout. Autumn was the typi- cal spawning season for the three trout species and the largest spawning season was for rainbow trout. The small size of the mature brook trout was notable from this study. They matured at $17.5 \mathrm{~cm}$ in length for females and $12.4 \mathrm{~cm}$ for males at age $2+$, which seems to be a particular characteristic of this species. In this study, both females and males matured at the same age. However, other authors have reported that the age at sexual maturity in brook trout varies among populations. Males normally mature before females (Mullen 1958), as early as age $0^{+}$(Buss \& McCreary 1960, Hunt 1965) and maybe as small as $8.9 \mathrm{~cm}$ length at first maturation (McFadden 1961). In contrast, Behnke (2002) recorded populations of stream-resident brook trout that matured at age $2^{+}$, with males usually maturing before females and as early as age $1^{+}$(Adams et al. 2008). According to Moyle \& Cech (2000), in less predictable environments, where adult survival probabilities are low, natural selection favours females who reproduce as young as possible, reflecting the situation for brook trout in this region of Chile.

Female rainbow and brown trout were both recorded at maturity stage VII. These fish had already spawned. They had diminutive oocytes present in the gonads and some larger oocytes free in the body cavity, clearly indicating that these fish were repeat spawners and had already previously spawned at least once. In autumn 2012, a single male, fish farm escapee, with much visceral fat, was recorded in stage $\mathrm{V}$ of maturity. Several fish farms, rearing rainbow trout in sea cages, are situated along the coastline near the Palena River's outflow. Although the survey indicated that the number of such escapees was low during the survey, there is a more general concern in Chile that consistent and large escapes of fish farm rainbow trout could affect the genetics of resident trout established stocks and reduce their ability to survive and thrive in a wild environment. In turn, it could affect the value of the recreational angling industry in Chile (Sepúlveda et al. 2013).

Overall the study showed that the Palena River catchment holds an abundance of well-conditioned rainbow trout and brown trout, supporting a thriving recreational angling fishery. However, permanent monitoring of fish stocks should be established to ensure a sustainable recreational fishery that will attract both Chilean and foreign tourist anglers. The low abundance and small average size of the brook trout recorded throughout the study indicate that the populations of brook trout in the main stem and the larger tributaries of the Palena River are not robust. There is, therefore, a need to protect this vulnerable species. Accordingly, it would be advisable to introduce fishery regulations that will limit the recreational harvest of these fish to avoid its extinction. 


\section{ACKNOWLEDGMENTS}

This study was carried within the framework of Project FIC- 30115221-0, with financial support from the Regional Government of Los Lagos Region. Our special thanks to Rolf Schilling, angler guide who collaborated with us during the whole period of study in the collection of fish samples. We are also thankful to Verónica Pozo, María José Cuevas, Elba Cayumil, Cristián Monroy, Marcelo Cáceres, Carolina Rodríguez, and Carlos Leal, who worked on the field sampling and in the processing of the samples at the laboratory.

\section{REFERENCES}

Adams, P., James, C. \& Speas, C. 2008. Brook trout (Salvelinus fontinalis) Species and conservation assessment. Grand Mesa, Uncompahgre, and Gunnison National Forests, Colorado.

Arismendi, I., Penaluna, B. \& Soto, D. 2011b. Body condition indices as a rapid assessment of the abundance of introduced salmonids in oligotrophic lakes of southern Chile. Lake and Reservoir Management, 27: 61-69.

Arismendi, I., Sanzana, J. \& Soto, D. 2011a. Seasonal age distribution of introduced resident rainbow trout (Oncorhynchus mykiss Walbaum) reveals lake-inlet fish movements in southern Chile. International Journal of Limnology, 47: 133-140.

Arismendi, I., González, J., Soto, D. \& Penaluna B. 2012. Piscivory and diet overlap between two non-native fishes in southern Chilean streams. Austral Ecology, 37: 346-354.

Arismendi, I., Soto, D., Penaluna, B., Jara, C., Leal, C. \& León-Muñoz, J. 2009. Aquaculture, non-native salmonid invasions, and associated declines of native fishes in lakes of the northern Chilean Patagonia. Freshwater Biology, 54: 1135- 1147.

Arismendi, I., Penaluna, B.E., Dunham, J.B., García de Leaniz, C., Soto, D., Fleming, I.A., et al. 2014. Differential invasion success of salmonids in southern Chile: patterns and hypotheses. Reviews in Fish Biology and Fisheries, 24: 919-941. doi: 10.1007/ s11160-014-9351-0

Basulto, S. 2003. El largo viaje de los salmones: una crónica olvidada: propagación y cultivo de especies acuáticas en Chile. Maval Limitada Editores, Santiago.

Behnke, R.J. 2002. Trout and salmon of North America. Free Press, New York.

Behnke, R.J. 1980. A systematic review of the genus Salvelinus. In: Balon, E.K. (Ed.). Charrs salmonids fishes of the genus Salvelinus. Springer, Berlin, pp. 441-480.

Buria, L.M., Albariño, R.J., Modenutti, B.E. \& Balseiro, E.G. 2009. Temporal variations in the diet of the exotic rainbow trout (Oncorhynchus mykiss) in an AndeanPatagonian canopied stream. Revista Chilena de Historia Natural, 82: 3-15.

Buria, L.M., Albariño, R.J., Díaz-Villanueva, V., Modenutti, B. \& Balseiro, E. 2007. Impact of exotic rainbow trout on benthic macroinvertebrate community from Andean-Patagonian headwater streams. Fundamental and Applied Limnology, 168: 145-154.

Buss, K. \& McCreary, R. 1960. A comparison of egg production of hatchery-reared brook, brown, and rainbow trout. Progressive Fish-Culturist, 22: 7-10.

Dahl, K. 1917. Studier og fors $\varnothing k$ over $\varnothing$ rret og ørretvand. Centraltrykkeriet, Oslo.

Dazarola, G. 2019. Historia de la Piscicultura Río Blanco. Escuela de Ciencias del Mar, Valparaíso.

Davaine, P. \& Bealle, E. 1992. Relationships between temperature, population density, and growth in a sea trout population (Salmo trutta L.) of the Kerguelen Islands. ICES Journal of Marine Science, 49: 445-451.

Food and Agriculture Organization (FAO). 1975. Manual of fisheries science part 2.5. Sex, maturity and fecundity. FAO, Rome. [http://www.fao.org/docrep/ 003/f0752e/f0752e05.htm]. Reviewed: March 17, 2017.

Ferriz, A. 1984. Alimentación del puyen Galaxias maculatus (Jenyns) en el Río Limay, Provincia de Neuquen. Physis, 42: 29-32.

Froese, R. 2006. Cube law, condition factor and weightlength relationships: history, meta-analysis and recommendations. Journal of Applied Ichthyology, 22: 241253.

Hunt, R.L. 1965. Dispersal of wild brook trout during their first summer of life. Transactions of the American Fisheries Society, 94: 186-188.

Jonsson, B. \& Jonsson, N. 2011. Ecology of Atlantic salmon and brown trout. Habitat as a template for life histories. Fish \& Fisheries Series, Corvallis.

Kuroda, J., Maraboli, L.E., Nordahl, C. \& Roa, R. 2009, Evaluación de la calidad de la pesca en el sistema del Lago Traful. Informe final. Centro de Ecología Aplicada del Neuquén, Neuquén.

Macdonald, J.S. \& Green, R.H. 1983. Redundancy of variables used to describe importance of prey species in fish diets. Canadian Journal of Fisheries and Aquatic Sciences, 40: 635-637.

McFadden, J.T. 1961. A population study of the brook trout, Salvelinus fontinalis. Wildlife Monographs, 7: 773. 
Macchi, P.J., Vigliano, P.H., Pascual, M.A., Alonso, M., Denegri, M.A., Milano, D., et al. 2008. Historical policy goals for fish management in northern continental Patagonia Argentina: a structuring force of actual fish assemblages? American Fisheries Society Symposium, 49: 331-348.

Meehan, W.R. \& Bjornn, T.C. 1991. Salmonid distribution and life histories: brook trout. Influences of forest and rangeland management on salmonid fishes and their habitats. American Fisheries Society Special Publication, 19: 78-79.

Moyle, P.B. \& Cech, J.J. 2000. Fishes: an introduction to ichthyology. Prentice-Hall, New Jersey.

Mullen, J.W. 1958. A compendium of the life history and ecology of the eastern brook trout, Salvelinus fontinalis Mitchill. Massachusetts Division of Fish and Game, Massachusetts.

Palma, A., Figueroa, R., Ruiz, V.H., Araya, E. \& Berríos, P. 2002. Composición de la dieta de Oncorhynchus mykiss (Walbaum 1792) (Pisces: Salmonidae) en un sistema fluvial de baja intervención antrópica: Estero Nonguén, VIII Región, Chile. Gayana, 66: 129-139.

Pascual, M., Bentzen, P., Riva-Rossi, C., Mackey, G., Kinnison, M.T. \& Walker, R. 2001. First documented case of anadromy in a population o introduced rainbow trout in Patagonia Argentina. Transactions of the American Fisheries Society, 130: 53-67.

Poole, R. (Ed.). 2010. Manual on sea trout ageing, digital scale reading and growth methodology. Celtic Sea Trout Project Workshop, Anglesey.

Received: 27 May 2020; Accepted: 24 August 2020
Raleigh, R.F. 1982. Habitat suitability index models: brook trout. United States Fish and Wildlife Service Biological Report 82, Colorado. [http://www.nwrc. usgs.gov/wdb/pub/hsi/hsi-024.pdf]. Reviewed: June 22, 2017.

Riva-Rossi, C., Pascual, M.A., Babaluk, J.A., GarciaAsorey, M. \& Halden, N.M. 2007. Intra-population variation in anadromy and reproductive life span in rainbow trout introduced in the Santa Cruz River, Argentina. Journal of Fish Biology, 70: 1-18.

Sepúlveda, M., Arismendi, I., Soto, D., Jara, F. \& Farias, F. 2013. Escaped farmed salmon and trout in Chile: incidence, impacts, and the need for an ecosystem view. Aquaculture Environment Interactions, 4: 273283.

Soto, D., Arismendi, I., González, J., Sanzana, J., Jara, F., Jara, C., Guzmán, E. \& Lara, A. 2006. Southern Chile, trout and salmon country: invasion patterns and threats for native species. Revista Chilena de Historia Natural, 79: 97-117.

Vigliano, P.H., Lippolt, G.E., Juncos, R., Macchi, P., Alonso, M.F., Denegri, M.A. \& Hougham, V. 2009. Evaluación y modelado de las poblaciones de peces del lago Traful con miras al desarrollo de una pesquería recreacional distintiva. Informe final. Autoridad Interjurisdiccional de las Cuencas de los Ríos Limay, Neuquén y Negro, Cipolletti. 